\title{
A Survey-Based Qualitative Analysis of the Institutional Structures and Policy Measures in the Shea Sector of Ghana
}

\author{
Martha Adimabuno Awo ${ }^{1}$ \\ ${ }^{1}$ Institute of Statistical, Social and Economic Research, University of Ghana, Legon, Ghana \\ Correspondence: Martha Adimabuno Awo, Institute of Statistical, Social and Economic Research, University of \\ Ghana, Post Office Box LG74, Legon, Accra, Ghana. E-mail: martawoadi@gmail.com
}

Received: May 24, 2018

doi:10.5430/rwe.v9n2p24
Accepted: July 29, 2018

Online Published: December 9, 2018

URL: https://doi.org/10.5430/rwe.v9n2p24

\begin{abstract}
Shea is an important tree crop for women in the three impoverished northern regions of Ghana and is considered to be a major source of poverty alleviation in these regions. The crop is picked in the wild as nuts mainly by women who sell the nuts to processors. These nuts are processed into butter and soap for local use and/or for exports. Institutional structures, from a variety sources including the cultural environment, community support systems and the State regulatory and support mechanisms, shape the opportunities, constraints and obstacles facing women pickers and local processors who rely on shea as an important source of income and economic empowerment. Both State and non-State institutions in Ghana have designed various policy interventions and programmes for the shea sector with the objective of reducing market failures of the sector and to improve incomes of shea-producing households. Based on a relatively large survey of 405 shea-producing households in selected districts of the Northern Region of Ghana, this paper discusses the institutional structures and policy measures in the shea sector in Ghana. From the perspective of the survey respondents, there is not enough coordination of programmes and policies among the various institutions in the shea sector. Respondents feel that the shea sector is largely unregulated; various actors take actions mainly for their own benefits and not necessarily for the benefit of the whole sector. Organised groups of shea-producing households are more likely to improve their chances of being impacted by programmes and policies of State and non-State institutions than unorganized individual shea-producing households.
\end{abstract}

Keywords: Ghana, institutional structures, institutional support, market failures, policy measures, political economy of shea, shea trade, state institutions

\section{Introduction}

About 20 countries in Africa, from Senegal in West Africa to Sudan in East Africa, are the home of the shea tree (Vitellara paradoxa) (Bonkoungou, 1987). This shea belt (refer to Figure 1) is about 600 kilometres (km) wide and $5,000 \mathrm{~km}$ long (Food and Agriculture Organization (FAO), 1988). The shea tree is an important cash crop in the three northern regions of Ghana where it provides income that helps to reduce absolute poverty in those regions, considered to be poorest in Ghana (Ghana Statistical Service (GSS), 2013a). In Northern Ghana, shea nuts are largely picked by women in community-owned forests and/or privately-owned fields. The pickers sell these nuts directly to buyers and processers who transform them into soap and butter. Awo and Anaman (2016) suggest that the picking of shea nuts from community forests and/or forests often owned by male family members, constitutes a competitive industry as the individual harvests have little or no effect on the market prices of shea nuts within a given geographical location. Laube et al. (2017) indicate that the shea market in Ghana is characterized by oligopolistic processing companies which largely set the prices for processed shea products and also influence the prices of shea nuts.

Following the persistent decline of the cocoa industry in Ghana during the early 1970s, the government adopted shea as one of the non-traditional crops that it would promote to diversify the country's foreign exchange earnings. The cocoa industry regulator, the Ghana Cocoa Board brought shea under its wings with a separate shea department created as part of the Cocoa Board. The cocoa industry had traditionally been the major source of foreign exchange earnings for Ghana during the $20^{\text {th }}$ Century together with gold and forestry products. In recent times, the shea sector has become an important component of the Ghanaian economy through its contribution to foreign exchange earnings and as an increasingly important source of income to reduce poverty in the three northern regions. For example, in 
2015, the country earned about US\$33.6 million from shea nuts as reported by the Ghana Export Promotion Authority in 2016.

Between 1970 to 1994, shea nut trade was largely controlled by the State with the Ghana Cocoa Board and its affiliate company buying agency, the Produce Buying Company, being dominant players in the shea nut trade (Laube, 2015). Despite the adoption of shea as an important non-traditional crop promoted by Ghana Cocoa Board in the early 1970s, Stichting Nederlandse Vrijwilligers (SNV) (2006) argues that this move had put shea into a subservient position with respect to cocoa and reinforced an existing bias that shea competed with cocoa. With entrenched interests in favour of the production and marketing of cocoa, shea continued to receive little attention, a claim made by SNV (2006).

The dynamics of marketing shea products changed in Ghana in the mid-1990s with the increased role of the private sector in the local and international marketing of products. For example, between 1998 and 2000, apart from the Ghana National Procurement Agency (GNPA), which was the largest state institution involved in shea, marketing of the commodity was largely in the hands of the private sector. Government attempted to support the Cocoa, Coffee and Sheanut Farmers' Association but the impact on the revival of the shea sector had been weak (SNV, 2006). Wardell and Fold (2013) noted that state regulation of the shea sector was initially done indirectly through licensing and export control but progressively changed to direct involvement in purchasing operations. The government's inability to regulate the shea trade effectively cemented the transition to governance by oligopoly (Wardell and Fold, 2013).

Over the past years, the shea butter industry has contributed to the livelihoods of numerous women and their families in the three northern regions of Ghana. As part of the State's portfolio of non-traditional agricultural commodity exports, the government of Ghana has continuously reaffirmed its intention to expand the shea nut production and trade. The activation of a vigorous programme to achieve this intention has however been lacking. For example, the shea sector lacks a national commodity board similar to that accorded cocoa, a crop largely grown in the wealthier southern parts of the country. Further as noted by Jibreel et al. (2013) there are no coherent policies to support the industry and a legal framework that backs the production and marketing regulations for the sector is lacking. The establishment of the Cocoa Research Institute at Bole (in the Northern Region) meant to research the development of cultivable species of shea trees could be gauged as representing an increased interest in shea by the government (Issahaku et al., 2011). However, the name of the Institute (with cocoa rather than shea) is an example of the conflict of interests that the government seems to be experiencing when it comes to putting emphasis on shea as an important national commodity.

A review of the food and agriculture sector policies of the Government of Ghana, enshrined through its various medium term development programmes, and implemented by the Ministry of Food and Agriculture (MoFA), indicates inadequate prioritization of the shea industry and its products. MoFA is the lead agency of the government of Ghana responsible for the development of the whole agricultural sector. It facilitates the preparation of the Food and Agriculture Sector Development Policy (FASDEP) and the related Medium Term Agriculture Sector Investment Plan (METASIP). Both the FASDEP II and the related METASIP (2011-2015) provided inadequate policy direction and resources for the overall development of the shea industry.

Zakaria (2014) points to the fact that the government has a low influence on policy, has an unclear national policy and strategy, is not seen as a viable partner, and generally has a weak voice when it comes to giving the shea sector a direction. Following a period of three decades of extensive adoption neo-liberal policies by the government of Ghana starting with the structural adjustment programmes enacted in April 1983, with the support of the International Monetary Fund and the World Bank (Anaman, 2006), the government appeared to be moving towards comprehensive regional development especially to bridge the gap between the three northern Regions and other parts of the country (SADA, 2010; IFAD, 2007). Given the emphasis on development of the three northern regions, the shea industry has received renewed attention (Laube, 2015); this attention is yet to be translated into practical actions to assist the sector.

The Ministry of Trade and Industry's National Export Strategy for the Non-Traditional Sector (2012-2016) outlines action plans for the development and production of shea products. The national tree crop development policies and strategies also recognize shea as one of the valuable tree crops of the country. SNV (2006) argues that the Ghanaian government has no real stance on policy regarding the shea sector. In terms of pricing, the policies regulating the price of shea are virtually non-existent. Operating within a free market system, a few dominant local and international players appear to exploit female pickers who are often price takers and are often unorganized and lack adequate knowledge of local and international shea market conditions. Despite the re-statement of the importance of 
shea to the economy of Ghana by the government, the reality is that international and local trading companies have largely taken over the control of key aspects of the sector which have not been fully conducive to the empowerment of women pickers and their households.

There is relative paucity of data and information about the perceptions of shea-producing households towards the effectiveness and usefulness of government institutions and policies in the shea sector and the effectiveness of the role of community-based organizations in that sector in Ghana. This current study bridges the gap in knowledge in this area by building on an earlier work published in Research in World Economy journal, in 2015, which dealt with political economy analysis of the production, marketing and constraints of women shea nut farmers in the Northern Region of Ghana (Awo and Anaman, 2015). The 2015 published study was also based on a survey of shea-producing households and was carried out in 2013 involving 226 women. Despite the considerable problems that they face, the vast majority of respondents in the 2016 study (96\%) indicated that they had not received any type of assistance from government agencies in their shea activities and enterprises. However, several non-governmental organizations had assisted them through various training programmes in areas such as shea nut processing, financial management and records keeping (Awo and Anaman, 2015).

Given the background material presented, the broad objective of this study is to examine the shea sector in Ghana with emphasis on the effectiveness and usefulness of institutional structures and policy-related issues from the view point of actors in the sector principally the shea-producing households. Specifically, this study examines the following objectives from the perspective of survey participants: (1) the institutional structures in Ghana's shea sector, and (2) the policy frameworks in the shea sector. The rest of this paper is organized as follows: the next section deals with the review of the literature including an historical overview of the development of the sector and its challenges. The methodology of the study is then discussed in the third section of the paper followed by the results and the conclusions and policy implications.

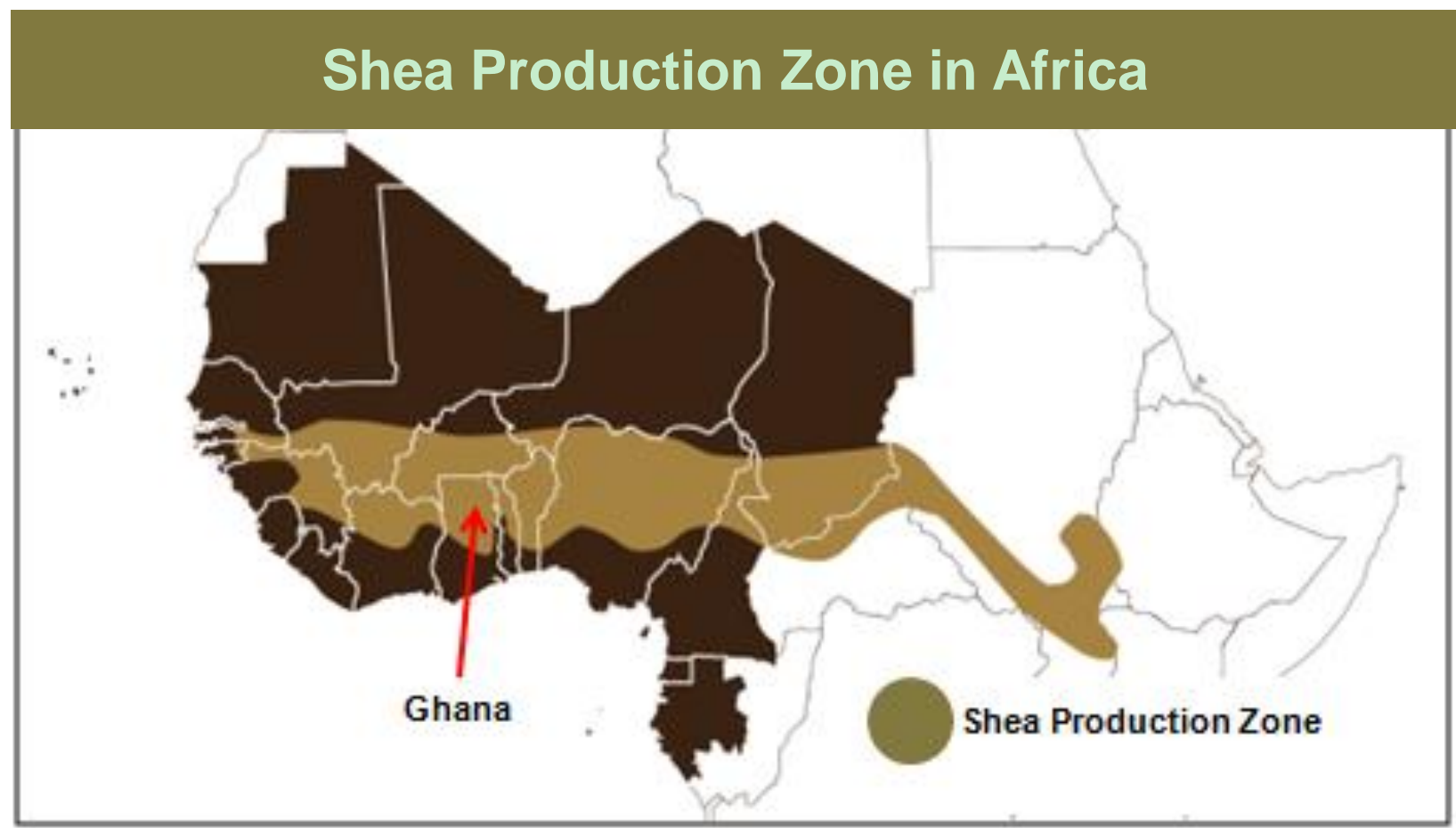

Figure 1. The African shea belt

Source: Elias and Carney, 2007, p. 38. 


\section{Literature Review}

\subsection{Historical Overview of the Shea Sector in Ghana}

Wardell and Fold (2013) have found historical evidence that suggests that the widespread production and trade of shea across the West African region had existed for centuries and dates back beyond European colonial rule in Africa. In Ghana, historically and culturally, shea-related activities have been largely confined to the three northern regions of the country where the shea trees are most ubiquitous (Laube et al, 2017). In recent times however, owing to climate change and its associated effects on the ecological landscape, sparse covers of shea trees have emerged in the Brong Ahafo, Ashanti, Eastern and Volta regions (Hatskevich et al., 2011; Fobi1, 2007).

Historical accounts of shea trade in Ghana indicate that shea butter was an important commodity of local and regional trade from the mid-nineteenth century often being in the return cargo of Volta River salt canoes (Wardell and Fold, 2013). It was an important exchange commodity between the Sahelian kingdoms in the north and the Akan kingdoms of the south. Furthermore, periodic market days served as hubs of trade in places such as Tamale, Bawku and Yendi, where village women traded their nuts and butter and by extension linked to external markets in Burkina Faso and Togo (Chalfin, 2004; Elias and Carney, 2007).

Early steps taken by the colonial administration in Ghana to promote shea included efforts to encourage the people of Adato diversify trade across the Volta beyond salt. According to Chalfin (2004), even though the colonial administration recognized that shea could be important if the barriers to its development were resolved, it only encouraged local production and not the export of shea products. The period after political independence in 1957 was another important historical era in shea production and trade in Ghana. Wardell and Fold (2013) note the shifting demand for shea kernels in the global market after the Second World War. In a quest for the newly independent Ghana to expand its tax and revenue base, attention was drawn to the shea sector. Chalfin (2004) explained that the involvement of the state in the early stages was indirect through licensing and the control of exports; however, this changed to direct state involvement over time. Pufaa (2010) notes that the regulation, purchasing and transportation of shea was facilitated by state agencies such as the Ghana Cocobod and its affiliate buying company, the Produce Buying Company especially from the early 1970s.

During the period of shea trade liberalization starting from mid-1990s, shea nuts experienced a decline in price on the international market which also coincided with a decline in cocoa prices (Bello-Bravo et al., 2015; Rousseau et al., 2015). The low international prices for the commodity coincided with the removal of restrictions on the participation of private companies. This factor altered the governance structure of the shea sector with several international private companies entering the mainstream operations of shea (Bello-Bravo et al., 2015). As Wardell and Fold (2013) note that several local individual entrepreneurs and small-scale companies also started operating in the sector.

In what is perhaps its biggest contribution to the sector, the government inaugurated a 115-member National Steering Committee on shea in 2011 which coincided with the establishment of a shea butter factory at Buipe. Hatskevich $e t$ al. (2011) observe that renewed state involvement in shea is seen with the inclusion of shea as one of the country's non-traditional exports, and in adopting shea production as a goal of the Ghana Cocoa Board.

\subsection{Review of the Challenges of Ghana's Shea Sector}

The shea sector of Ghana faces several problems starting from the tree stage to nut harvesting and butter processing, to making the final products. The absence of a Shea Development Board, and a Shea Research Institute that is backed by legislative instruments and policies is undoing the prospects that the sector provides for the country. The shea sector is faced with market challenges, especially following the 2008 global financial crisis. Butter processors, nut pickers, local agents, and manufacturers of roasting equipment faced a reduction in output and income.

Adams et al. (2016) reckon that the fact that shea trees are wild and grow naturally predispose them to destructive human activities including logging and bush burning. Additionally, because the growth of the plant is not controlled by man but rather by nature, it becomes hard to predict yields. Kent and Bakaweri (2010) alluded to the fact that the supply of shea is seasonal depending on the favourability of prevailing ecological factors. A combination of human activities and changing climatic conditions has increased the uncertainty surrounding the volumes of shea nuts picked within a particular season.

Reliance on traditional methods of processing shea retards efficiency of processing and quality of output resulting in lower prices for products (Al-hassan, 2012). Adams et al. (2016) opine that the laborious nature of traditional methods of processing does not only affect quality of output but can inflict physical harm to processors due to the effort exerted. Al-hassan (2012), in an assessment of shea nut processors in Ghana, found that access to markets is 
limited by poor entrepreneurial skills and lack of formal training. Suleman et al. (2014) examined the livelihood of women in the shea butter industry in Northern Ghana, identified limited financial support, high cost of inputs, lack of a ready market, inadequate water and fuel, and the tedious nature of processing, as the key challenges that hamper the processing of shea nuts into butter.

The shea picking process is also a major point of attention in Ghana as it is a point of multiple challenges to stakeholders. Local people are exposed to several hazards such as thorns, scorpions and snakes who feed on the fresh shea fruits. Pufaa (2010) notes that these challenges constrain the pickers so that about half of the shea harvest is left uncollected in the wild annually. Lack of information is also a key challenge to the shea sector in Ghana. Lovett (2004) concurs that across West Africa, shea trade networks are dominated by a general lack of access to information about market demand and quality-price structure. This he notes, leaves women as price-takers and prevents shea butter and kernels from being traded as profitable commodities. The formation of shea cooperatives by NGOs (such as SNV) is helping empower women by enhancing their access to market information and strengthening their bargaining capacities.

Awo and Anaman (2015) provide information on the nature of constraints faced women shea nut farmers in the Northern region of Ghana. They established that the farmer satisfaction of prices received for shea products was linked to his/her membership of farmer-based organization and the availability of enforceable contracts with buyers. They noted that the improvement of farmer's incomes and market outcomes had largely been through individual efforts and/or through the efforts of FBOs with relatively little role played by the State. The government of Ghana and its external development partners and various non-governmental organisations, and civil society organisations offer some level of training, technical assistance and market information to help improve the shea sector particularly targeting rural poor women.

\subsection{Market Failures and Role of Community Organizations and Institutions in Shea Sector}

The challenges and constraints in the shea sector in Ghana documented in the previous section can be considered to be failures of shea markets in Ghana. Essentially, the roles of community organizations are due to the failures of the various shea markets in production, consumption and distribution of goods and services. The existence and persistence of high levels of poverty among shea-producing households indicate the failures of the free markets in shea production and trade to provide adequate incomes for the survival and sustainability of people and their livelihood systems (Awo and Anaman, 2015). These market failures are due among other things to the inadequate level of competition with the dominance of more powerful trans-national corporations in the shea sector due to the increased internalisation of shea trade. However, other sources of market failure are related to the changing climate that has resulted in decreased yields, inadequate use of modern technology in production and processing, cultural practices that impose constraints on women in terms of access to resources in shea production and trade.

When markets fail, as they do often in many developing countries such as Ghana, alternative interventions are developed by the Community and the State to improve societal outcomes in terms of reducing poverty (Hayami, 1989; Hayami, 2009; Buadi et al., 2013; Anaman, 2014). In the context of shea sector in Ghana, the Community and State institutions that deal with market failures are the subject of this study. The discussion presented in the earlier sections has provided an overview of the numerous problems faced in the shea sector of Ghana.

It is apparent that more needs to be done by government institutions to translate the declared policies and re-stated policy intentions for the shea sector into action. With this current study, the quality of support from these institutions is analysis based on qualitative analysis with emphasis on the directly-elicited answers from shea producers, processors and traders using a relatively large survey. This study also elicits from the actors of the shea value chain specific policy actions that they would like to the government to undertake.

A synthesis of the literature review discussed in the previous sections indicates various challenges facing the shea sector in Ghana identified from various actors in the sector such as producing households, traders, exporters and government regulators, policy makers, and several academics and researchers. A motivation driving this study is the need to identify the types of constraints facing shea-producing households in terms of their own directly-expressed views of the usefulness of institutional structures in the sector and their perceptions of the quality of policy frameworks in the sector. Thus, this is motivated by the need for evidence of the usefulness and quality of the support systems backing the shea-producing households "from their own mouths" without complicated use of statistical analysis. 


\section{Methodology}

\subsection{Study Area}

The data collection for the study was undertaken using two main approaches: (1) a detailed survey of 405 respondents employing personal interviews of heads of shea producing households, (2) qualitative data collection based on interviews of key actors in the shea sector in both the survey area and key shea trading areas such as the major towns of Accra, Tema and Tamale. The survey was undertaken in the study area in the Northern Region and this study area is described next.

This study was conducted in Ghana because the country is well known for its shea activities and is well integrated into the Global Value Chain of shea. The Northern Region of Ghana was specifically selected for this study because it is situated within the shea belt of West Africa and produces a lot of shea and is considered the most important shea producing region in the country. The Northern Region occupies an area of about 70,384 sq. km (GSS, 2013b) and is part of Ghana's savannah belt earmarked by a semi-arid climate and a dry season between April and November (Laube et al, 2017). Rainfall is highly variable (Jasaw et al, 2015) with average rainfall of the region is between $900 \mathrm{~mm}$ and $1000 \mathrm{~mm}$. The major economic activity in the region is agriculture with smallholder food crop production and keeping of livestock being the major activities (Kusakari et al, 2014).

Three districts in the Northern region were selected for the study. These districts are Chereponi, West Gonja, and the Tamale Metropolis. These districts are among the highest shea producing districts in the Northern Region. Field work was conducted in Ghana in August, 2017. The communities for the study were selected purposively taking into account various baselines. The most important baseline considered was that the community is one that has shea activities going on, whether picking or processing or sales, or an amalgamation of all shea activities along the value chain. This information was gathered through documentary analysis, and interviews with Global Shea Alliance (GSA), SNV, Shea Unit of the Ghana COCOBOD, and reconnaissance surveys. The second parameter considered was the socio-economic characteristics of the districts in which the identified communities were located. Thus, using the Ghana Living Standards Survey (GLSS) reports and Census reports by the Ghana Statistical Service (GSS) as baselines, the districts were classified into high income, middle income, and low income.

The third parameter was to segregate the communities into the ones with shea cooperatives, and the ones without shea cooperatives. This was successfully identified with assistance from SNV Ghana who was engaged in several shea cooperative activities in the Northern region of the country. Distance was a key factor in selecting the communities without shea cooperatives. Thus communities that had no cooperatives but were close to communities with cooperatives were not considered. This was to prevent the possibility of contamination of data which could arise from both cooperative and non-cooperative community being proximate to each other.

In each district, two communities were selected, that is, one with a shea cooperative and the other without a shea cooperative. However, in the course of listing of communities, field assistants were given the freedom to select from a reserve list of communities if their population samples in the selected community fell short of the required number. After taking the various parameters into consideration, and after listing by the field assistants in all the districts, the following communities indicated in Table 1 were selected for the study.

Table 1. List of communities surveyed

\begin{tabular}{lll}
\hline Ghana & & \\
\hline Chereponi District & Cooperative & Non-cooperative \\
\hline & Yeteli & Tigenga \\
\hline & Naboni & Nawieku \\
\hline West Gonja District & Busunu & Murugu \\
\hline Tamale Metropolis & Cheshe & Pagazaa \\
\hline
\end{tabular}

Source: Shea survey, 2017

\subsection{Qualitative Data Collection and Analysis}

As indicated earlier, qualitative data collection based on interviews of key actors in the shea sector in both the survey area and key shea trading areas such as the major towns of Accra, Tema and Tamale. Qualitative data collection for 
the study was done using various qualitative approaches including in-depth interviews (IDIs) at institutional and household levels and also focus group discussions (FGDs) in the communities of study. Separate instruments were designed for collection of qualitative data for government institutions, women's' groups, NGOs, private companies, assemblymen and women, chiefs and opinion leaders.

The qualitative data collection was done in three phases. The first phase was done in Accra and Tema. The key actors in the shea industry that were successfully interviewed in this phase include $3 \mathrm{~F}$ limited, Shea unit of COCOBOD, Global Shea Alliance, IOI Loders, Ministry of Food and Agriculture, and Peini Ghana limited. The second phase of the qualitative data collection took place in Tamale. Various institutions including government agencies, NGOs, private companies and heads of women`s cooperatives were interviewed. The institutions from which interviews were conducted in Tamale include: COCOSHE, Hajara Bobobo women farmers processors marketers group, Shea Network Ghana, Savanah Accelerated Development Authority (SADA), Sheaxeen natural, SNV, Tunteiya Cooperative, and MOFA.

The third phase of the qualitative data collection was done in the communities of study. This involved both in-depth interviews (IDIs) and focus group discussions (FGDs). For each district of study, two focus group discussions, one in each community was conducted. Furthermore, ten in-depth interviews, five in each community were conducted. Thus from the study communities, 60 in-depth interviews for head shea pickers of households were conducted. Additionally, a total of 12 focus group discussions were conducted. In addition to these sources of qualitative data, interviews were conducted for NGOs, government institutions, Chiefs/elders of communities, assemblymen/women, and head of cooperatives to provide information to augment the ones obtained from the household and focus group discussions.

\subsection{Institutions Covered During the Data Collection}

The first phase of the data collection component of the study for institutions was done in Accra and Tema. Even though a number of institutions were contacted to permit the conduct of interview, the successfully engaged institutions are 3F limited, Shea unit of Cocobod, Global Shea Alliance, IOI Loders, Ministry of Food and Agriculture, and Peini Ghana Limited. For the second phase of data collection which occurred in Tamale, the institutions from which interviews were successfully conducted in Tamale include: COCOSHE, Hajara Bobobo women farmers processors marketers group, Shea Network Ghana, Savanah Accelerated Development Authority (SADA), Sheaxeen natural, SNV, Tunteiya Cooperative, and MOFA WIAD unit.

The third phase of data collection for institutions occurred within the sampled communities where interviews were conducted for NGOs, Government Institutions, Chiefs/Elders of communities, Assemblymen/women, and head of cooperatives to provide information to augment the ones obtained from the household and focus group discussions. The 405 interviewed shea-producing households were also specifically asked questions relating to the institutions and their services for the shea sector.

\section{Results}

\subsection{Basic Socio-economic Information About Respondents}

Table 2 presents information about selected socio-economic indicators of the 797 respondents who took part in the formal survey. The vast majority ( $86 \%$ ) of the respondents were women, largely representing the female dominance of the shea picking and primary processing industry. Almost half of the respondents $(47.8 \%)$ of the respondents were between the ages of 36 to 59, which reflected the middle-age group. About three out of 10 respondents were under the age of 36 representing a fairly representation of the youth in the selected survey respondents. The mean age of the household head was 46.3 years; male-headed households were on average 45.7 years old while female-headed households were slightly older on average at 49.5 years. The majority of the respondents were married (86.3\%) with the ever-married proportion (married, divorced, separated and widowed) even much higher at $98 \%$.

About three-quarters of the respondents had never received any formal education. The remaining one-quarter of respondents were enrolled in school at the time of the survey or had completed schooling and had achieved some formal educational attainment. About four out of 10 respondents (39.1\%) had at least one savings account. Slightly over four out of 10 respondents $(43.5 \%)$ were members of producer/processor associations. In a summary, the respondents generally had little formal education and were mainly young or middle-aged people. Around four out of 10 respondents belonged to producer organizations and had savings accounts. This summary picture suggested an important role of community-based organizations, governmental and non-governmental institutions in assisting shea-producing households to deal with the challenges of the shea sector and market failures associated with low incomes of households. 


\subsection{Types of Support Services and Inputs Received From Institutions}

Table 3 provides information on the types of support received by the 405 survey shea-producing households from various institutions and related agencies. The general picture from Table 3 indicates limited support and assistance received from various institutions in the survey area by the sampled shea-producing households. The support services indicated in Table 3 are the supply of inputs, training, and the introduction of new methods of picking, processing and trading shea products. Non-government organizations (NGO) was by far the most prominent institutional structure assisting shea-producing structures in the three key areas of support services. But even for NGOs, the level received by shea-producing households was limited with $11.7 \%$ of respondents indicating that they received training from NGOs. Incidentally, this proportion was the highest for any category of support services and for any institutions.

The case of the role of government agencies and institutions was nothing to write home about. In terms of the critical role of information related to the introduction of new methods of picking, processing and trading shea products, survey respondents ranked the government as the worst institution with only $0.8 \%$ of the respondents indicating that they had received some information from government agencies in this area. The role of other institutions such as business companies was also generally limited in all three areas of support services to shea-producing households. Given the very clear limited role of institutions in supporting shea-producing households, the approach used for the assessment of institutions was to report the direct views expressed by these households. These views are outlined in Sections $4.3,4.4$ and 4.5 of this paper.

Table 2. Summary of socio-economic characteristics of survey respondents

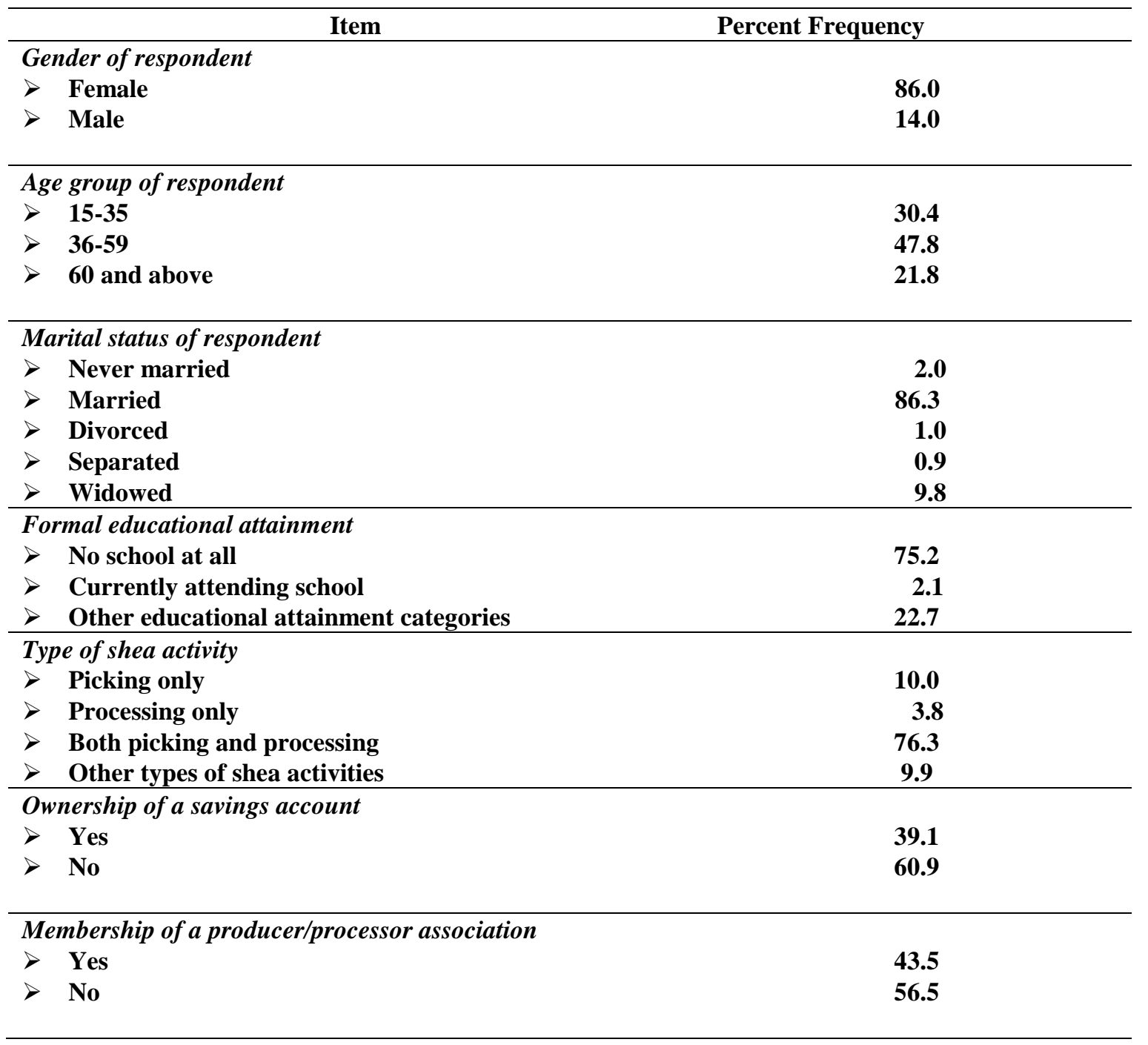


Table 3. Types of support received from various institutions in the survey area by the 405 sampled respondents

Category of support or service received by survey respondents Percentage

Received inputs from:

Government institutions and agencies such as extension services

\section{Received training from:}

Government institutions and agencies such as extension services

NGO/NSA

Others - company/business/individual

Received any new method of how to pick, process and market shea from:
1.0

11.7
Government institutions and agencies such as extension services NGO/NSA

Others - company/business/individual
0.8

6.2

2.6

\subsection{Respondents' Qualitative Assessment of Challenges of Institutions in the Shea Sector}

There were two main challenges regarding the involvement of institutions in these communities. Firstly, there seems to be problem with the enforcement and implementation of the existing directives that have been put in place. For a variety of reasons, these directives are often not followed hereby endangering the shea supply or the pickers themselves.

Interviewer: But does the Assembly not have bye laws to protect the shea trees?

Respondent: The bye laws are there but how to implement them. You know, our people here, even sometimes you will not even get them; the smokers, even some will even burn it intentionally or maybe they can.

\section{- KII Chereponi Assemblyman}

Interviewer: Is that we do not have the implementation bodies or what?

Respondent: Enforcement, who will enforce it?

Interviewer: But the one who enact the bye laws, do not they identify the implementation bodies?

Respondent: You see, for instance, all that we are talking about shea and shea, we are the implementation bodies, but we have no teeth to bite. Are you getting the whole...?

\section{- KII Chereponi WIAD}

The other problem the producers face is marketing. Even when they are in groups or have other institutions giving them aid, they still struggle with being unable to control the prices and often function as price-recipients. Often, as shown in 
the first example, the individuals who dictate these prices are the institutions supposed to be aiding the pickers. However, these participants do not see this as a particularly important problem and are willing to accept the prices dictated.

Interviewer: Who determines the price?

Respondent: It is the institution which determines the price.

Interviewer: As compared to the price at Sabou which one is better?

Respondent: There is an advantage here even if the price is low. Because the institution comes in times of difficulties, when women take the money they use it to support their needs.

Interviewer: So even if the price is too low you are ok with it?

Respondent: Yes.

Interviewer: What other profit do you get from the group?

Respondent: There are no other profits.

\section{- FGD Sourgou}

\subsection{Respondents' Qualitative Assessment of Institutions in the Shea Sector}

With regards to institutional support, interviewees referred to aid from a variety of both Governmental and Non-Governmental Organizations (NGOs). These institutions include the Ministry of Food and Agriculture (MOFA), USAID, the NGO AKK, and Tree-Aid. This aid often comes in several forms as shown in the following paragraphs. Many of the interviewees were members of cooperatives whose objective was to achieve certain goals (usually economic).

Respondent: The name of the cooperative is Suglo mboribuni, which literary means acquisition of wealth is by patience.

\section{- KII Pagazaa Cooperative Leader}

Some still talked about not receiving any aid from any institutions at all and did not have any formed intuitions at all - as these women in the FGD in Kougsin admit:

Interviewer: Are there NGOs that help you?

Respondent: No, we do not get any help we do it on our own.

Interviewer: You do not get help from government too?

Respondent: No

Interviewer: Do you have any cooperative here?

Respondent: No, we do not have any group.

\section{- FGD Kougsin}

The functions of this cooperative seems to depend on the area in which it is located. Some of the cooperatives are formed to provide a buying group within which the women could receive fair prices for their products. These women in the example below had such an arrangement.

Interviewer: Do you have a cooperative group that pick the shea together?

Respondent: No.

Interviewer: Who is a cooperative member?

Respondent: The cooperative is not for picking the shea but rather to buy shea. There is this institution that come and gives us money to buy shea for them.

\section{- FGD Sourgou}

Respondent: There is an institution that comes here to give us money to buy the shea and they come back to weigh the shea.

Interviewer: Is it in the form of loans?

Respondent: Yes, it is a loan.

Interviewer: And what do you do with the money? 
Respondent: We buy shea nuts with the money.

Interviewer: Do they give you the money in group?

Respondent: We take the money in group and share it among us.

- FGD Sourgou

Some of the NGOs provide the pickers with tools that they could use to pick the shea with reduced trouble. One thing that came up often was a picker that the women used to pick the sea off the ground.

Interviewer: Has any individual or institution supported or gifted you some shea implements?

Respondent: They brought some shea pickers some time ago.

- IDI Yiteli

Respondent: We have not received any support like that. It is only this year that they brought something that can be used to pick shea nuts from the bush. It is called Shea picker. We took it on credit and we will pay it bit by bit. The machine is very helpful. You don't have to bend down to pick the shea nuts. It is really helpful.

- KII Yiteli Cooperative Head.

The groups were also responsible for educating these communities on various issues concerning shea production and marketing. This seemed to be the highest occurring theme in the discussions with the interviewees as demonstrated in the following example:

Respondent: We have been educated on a lot of things that are helping us to improve our livelihoods. The cooperative offers us the opportunity to borrow money during the lean season to buy food. Now we have also learned not to burn shea trees. The group has also taught us how to invest shea income in other profitable ventures such as livestock rearing. Shea has helped to take care of my child up to SHS level.

\section{- FGD Sourgou}

On the part of the Governmental Institutions, there seem to be some directives in place that are aimed at helping shea picking communities to function and develop. Some of these are meant to directly protect the shea trees as shown in the IDIs from Kougsin below.

Respondent: Here we do not cut the trees if you cut it you will be caught.

Respondent: Here we have forest guards who monitor what goes on in the bush.

Respondent: If one is caught cutting a tree the person is fined serving a lesson to others.

Other directives are result of the international rules for the purchasing grade of shea products. These rules often result in higher value for the products but are often difficult to meet and assess.

Interviewer: The shea butter and fair trade, is it one of the fair trade...

Respondent: Yes, they have. Which they recognize and certify as fair trade.

Interviewer: Wow that means it is having value now because in the past it was just a local product processed but then if fair trade is coming in it means it can change the...

Respondent: They've been in the system already.

$$
\text { - KII Contrapac (Pieni) }
$$

The Ministry of Food and Agriculture (MoFA) also has several directives in place that aimed at helping the communities in their daily lives. These directives range from nutrition education to improving the quality of their products. Some of these directives are summarized in the following examples from the KII with MoFA WIAD in Tamale:

So, for shea, if you want to narrow to shea, our main biggest advocacy too is on quality; because we want to improve incomes. So, for incomes to improve, you'll realize you should do it to its quality standard. It means, if you want to meet quality, right from the chain, how are you doing the processing? Because, the way you start it will affect the outcome or the final product. So, they are just small things that we normally preach on.

I will add hygiene aspect to it; because it's also big, very big. In this era where the labour force is not there, so on the farm, right from the production stage, you will realize farmers are using a lot of chemicals, how are they using it? It's a concern! So, we normally do advocacy by using documentaries. 


\subsection{Respondents' Assessments of the Policy Measures in the Shea Sector}

The stakeholders interviewed also addressed the directions that they anticipated or hoped that future policy would take. These included hopes for policies that would increase the shea cover:

Respondent: We'll prefer to reforest with our shea, bring in more of the early maturing shea, into even our own shea fields.

$$
\text { - KII Necida (NGO) }
$$

Some interviewees, principally in the IDIs want some form of guaranteed prices in markets where they can easily sell their products. They expressed the desire that the government or other organizations (NGOs, international buyers) would give them more aid in their individual lives, and in the production and purchase of shea products. As shown in these examples.

There are no markets for our shea products so we are pleading to individuals, government, and NGOs to come and provide markets for us.

\section{- IDI Kougsin}

So, we are praying that some organisation will do their best to come and put up the storage structures for us so that our business in shea will increase.

\section{- KII Yiteli Cooperative Head.}

Other interviewees, particularly the key informants, addressed the problem of market regulation and the ways in which policies could address the current inequalities in market pricing and the disadvantages the women face due to their inability to control prices. Some also spoke about the regulation of the market. This is shown in examples below:

Respondent: It will not be under COCOBOD and then you will be having the levies that COCOBOD is having and so you will have the money to work on it. So, you will be able to regulate the industry. You can regulate the people who are into it, the enterprises, you can build the women group enterprises, you can even sponsor some new products from shea. So, you have the funds to do all these things.

$$
- \text { KII SADA }
$$

Interviewer: Would you have wish that the pricing could be regulated by government or you like the free market?

Respondent: I think it is appropriate it is not regulated by government but they need to understand the finance part of it.

Interviewer: The pickers or the government?

Respondent: Not the government but the cooperative groups of course including pickers.

$$
\text { - KII Contrapac (Pieni) }
$$

\section{Conclusions}

This study involves a survey of shea-producing households in the Northern region of Ghana that uses qualitative tools to analyse the institutional structures and policy measures in the shea sector. Shea-producing households face considerable barriers and constraints. Enhanced and informed policies are critical in ensuring the relaxation of obstacles and constraints faced by women pickers and other participants in the shea value chain in Ghana. Both State and non-State institutions in Ghana have designed various policy interventions for the shea sector with the objective of reducing market failures of the sector and to improve incomes of shea-producing households. Although, the government's shea sector programmes and initiatives are managed under Ghana COCOBOD, it is evidently clear from the responses of stakeholders in the sector that the shea sector is less structured and far less organized compared to the cocoa sector. There are not many established institutions along the shea value chain.

From the perspective of the survey respondents, there is not enough coordination of programmes and policies among the various institutions in the shea sector. The sector is largely unregulated and the various actors take actions mainly for their own benefits and not necessarily for the benefit of the whole sector. Respondents generally asserted that having organized groups of shea pickers in a community improves their chances of being positively impacted by shea policies; communities with fewer or no organised group of pickers experience lesser impacts from government and community shea development programmes. Organised and cooperative shea groups are able to get good bargains for their products. The issue of exploitation by middlemen and international companies operating in the shea sector is minimised in the presence of co-operatives as compared to non-cooperatives. 
The economic empowerment of shea pickers is a key focus of the majority of the civil society organisations and NGOs operating in the shea sector in the study area. Their interventions are mostly targeted at getting better prices for shea pickers and processed shea butter producers. Women are mostly the beneficiaries of these interventions. State institutions advocate and push for similar policies related to guaranteed prices and market for shea products. State institutions are not very much active in production and processing extension activities. As suggested by Awo and Anaman (2015), this study recommends an increased role for State institutions, especially the Ministry of Food and Agriculture, in providing re-invigorated extension services, to empower shea-producing households improve their incomes. Further, government agencies need to develop improved market infrastructure for the shea-producing areas to reduce the costs of travelling from homes to farms and from farms to marketing centres through the improvement of motorable roads, bridges and farmer market centres.

\section{Acknowledgments}

I thank the participating producers and processors in Ghana for their cooperation in response to our survey. My appreciation is extended to Volkswagen Foundation, Germany for financing the study. I acknowledge the comments of Kwabena A. Anaman in the development of this paper.

\section{References}

Adams, A. M., Abudulai, I., \& Bashiru, M. (2016). The Shea Industry and Rural Livelihoods among Women in the Wa Municipality, Ghana. Journal of Social Science Studies, 3(2), 40-56. https://doi.org/10.5296/jsss.v3i2.8706

Al-hassan, S. (2012). Market Access Capacity of Women Shea Processors in Ghana. Retrieved 1 May, 2018, from http://udsspace.uds.edu.gh/handle/123456789/1037

Anaman, K. A. (2006). Determinants of Economic Growth in Ghana. Accra, Ghana: Institute of Economic Affairs.

Anaman, K. A. (2014). Research Methods in Economics and Other Social Sciences Second Edition. Saarbrucken, Germany: Lambert Academic Publishing.

Awo, M.A., \& Anaman, K.A. (2015). Political Economy Analysis of the Production and Marketing of Shea Nut Products by Women in the Northern Region of Ghana. Research in World Economy, 6(4), 1-17.

Bello-Bravo, J., Lovett, P. N., \& Pittendrigh, B. R. (2015). The Evolution of Shea Butter's "Paradox of Paradoxa" and the Potential Opportunity for Information and Communication Technology (ICT) to Improve Quality, Market Access and Women's Livelihoods across Rural Africa. Sustainability, 7(5), 5752-5772. https://doi.org/10.3390/su7055752

Bonkoungou, E. (1987). Monographie du Karité Butyrospermum Paradoxum (Gaertn. f.) Hepper, Espèce Agroforestière à Usage Multiple, Ouagadougou, Burkina-Faso, Institut de Recherche en Biologie et Ecologie Tropicale.

Buadi, D. K., Anaman, K. A., \& Kwarteng, J. A. (2013). Farmers' Perceptions of the Quality of Extension Services Provided by Non-governmental Organisations in Two Municipalities in the Central Region of Ghana. Agricultural Systems, 120, 20-26. https://doi.org/10.1016/j.agsy.2013.05.002

Chalfin, B. (2004). Shea Butter Republic: State Power, Global Markets, and the Making of an Indigenous Commodity. London: Routledge. https://doi.org/10.4324/9780203496534

Elias, M., \& Carney, J. (2007). African Shea Butter: A Feminized Subsidy from Nature. Africa, 77(11), 37-62. https://doi.org/10.3366/afr.2007.77.1.37

Fobil, J. N. (2007). Research and Development of the Shea Tree and its Products. New Haven. Connecticut, United States: Horizon Solutions International.

Ghana Export Promotion Authority (GEPA). (2016). Non-Traditional Export Performance Report 2015. Accra : GEPA.

Ghana Statistical Service (GSS). (2013a). 2010 Population and Housing Census: National Analytical Report. Accra: GSS.

Ghana Statistical Service (GSS). (2013b). 2010 Population and Housing Census: Regional Analytical Report, Northern Region. Accra: GSS.

Hatskevich, A., Jenicek, V., \& Darkwah, S. A. (2011). Shea industry - A Means of Poverty Reduction in Northern Ghana. Agricultura Tropica et Subtropica, 44(4), 223-228.

Hayami, Y. (1989). Community, Market and State. In Maunder, A.A. and Valdes, A. (Eds.), Proceedings of the $20^{\text {th }}$ International Conference of Agricultural Economists, Buenos Aires, Argentina (pp. 24-31). London: Dartmouth. 
Hayami, Y. (2009). Social Capital, Human Capital, and the Community Mechanism: Toward A Conceptual Framework for Economists. Journal of Development Studies, 45(1), 96-123. https://doi.org/10.1080/00220380802468595

International Fund for Agricultural Development (IFAD). (2007). Northern Rural Growth Programme: Project Design Document. Rome: IFAD.

Issahaku, H., Al-hassan, R., \& Sarpong, D. B. (2011). An Analysis of Allocative Efficiency of Shea Butter Processing Methods in the Northern Region of Ghana. Retrieved 1 May 2018, from http://udsspace.uds.edu.gh/handle/123456789/425

Jasaw, G. S., Saito, O., \& Takeuchi, K. (2015). Shea (Vitellariaparadoxa) Butter Production and Resource Use by Urban and Rural Processors in Northern Ghana. Sustainability, 7(4), 3592-3614. https://doi.org/10.3390/su7043592

Jibreel, M. B., Mumuni, E., Al-Hassan, S., \& Baba, N. M. (2013). Shea Butter and its Processing Impacts on the Environment in the Tamale Metropolis of Ghana. Retrieved 1 May 2018, from http://udsspace.uds.edu.gh/handle/123456789/1043

Kent, R., \& Bakaweri, C. (2010). Mechanisms to Ensure Participation in Shea Value Chain: A Case Study of Two Interventions in Northern Ghana. In Food and Agriculture Organization Trade and Markets Division Workshop on Institutional Innovations and Policy Interventions in Support of Smallholder Markets Participation (pp. 3-4). Rome: Food and Agriculture Organization.

Kusakari, Y., Asubonteng, K. O., Jasaw, G. S., Dayour, F., Dzivenu, T., Lolig, V., \& Obeng, F. K. (2014). Farmer-perceived Effects of Climate Change on Livelihoods in Wa West District, Upper West Region of Ghana. Journal of Disaster Research, 9, 516-528. https://doi.org/10.20965/jdr.2014.p0516

Laube, W. (2015). Global Shea Nut Commodity Chains and Poverty Eradication in Northern Ghana: Myth or Reality?. Retrieved 1 May 2018, from http://udsspace.uds.edu.gh/handle/123456789/456

Laube, W., Awo, M. A., \& Derbile, E. K. (2017). Smallholder Integration into the Global Shea Nut Commodity Chain in Northern Ghana (No. 153). ZEF Working Paper Series. Retrieved 1 May 2018, from https://www.econstor.eu/handle/10419/162194

Lovett, P. N. (2004). The Shea Butter Value Chain: Production, Transformation and Marketing in West Africa. West Africa Trade Hub Technical Report No. 2. Accra: United States Agency for International Development.

Ministry of Food and Agriculture (MoFA) of the Republic of Ghana. (2018). Medium Term Agriculture Development Plan (METASIP). Retrieved 12 May 2018, from http://www.mofa.gov.gh/site/?page_id=315

Pufaa, F. E. (2010). Financing the Production and Marketing of Shea Butter in Tamale Metropolis. Retrieved 1 May 2018, from http://dspace.knust.edu.gh/handle/123456789/400

Reynolds, N. (2010). Investing in Shea in West Africa: A US Investor's Perspective. West Africa Trade Hub (WATH) Technical Technical Report No. 1, WATH. Accra: United States Agency for International Development (USAID).

Rousseau, K., Gautier, D., \& Wardell, D. A. (2015). Coping with the Upheavals of Globalization in the Shea Value Chain: The Maintenance and Relevance of Upstream Shea Nut Supply Chain Organization in Western Burkina Faso. World Development, 66, 413-427. https://doi.org/10.1016/j.worlddev.2014.09.004

Savannah Accelerated Development Authority (SADA). (2010). Synopsis of Development Strategy (2010-2013). Accra: SADA, Government of Ghana.

Seidu, S. B. (2012). Prospects and Challenges of the Shea Industry in the Northern Region of Ghana, Doctoral Dissertation, University for Development Studies, Tamale. Retrieved 1 May 2018, from http://udsspace.uds.edu.gh/handle/123456789/611

Stichting Nederlandse Vrijwilligers (SNV). (2006). Improving Market Access for Smallholder Farmers: Concept Note on Developing Shea Market Chains. SNV Shea Subsector Study. Tamale, Ghana: SNV.

Suleiman, D., Adjei-Mensah, C., \& Nutsugbodo, R. (2014). Urban Poverty in Northern Ghana: Tracing the Livelihood Strategies of Women in the Shea Butter Industry. Journal of Human and Social Science Research, $3(1), 15-25$.

Wardell, A., \& Fold, N. (2013). Globalisations in a Nutshell: Historical Perspectives on the Changing Governance of the Shea Commodity Chain in Northern Ghana. International Journal of the Commons, 7(2), 367-405. https://doi.org/10.18352/ijc.361

Zakaria, I. (2014). The State of the Shea Industry in Ghana. Updates. Tamale: Shea Network Ghana. 